\title{
Styrket feedback gennem studerendes selvevaluering
}

Lars Bo Andersen, postdoc, Institut for Kommunikation og Kultur, Aarhus Universitet.

\section{Faglig artikel (bedømt af redaktionen)}

Studerende er ofte utilfredse med såvel kvaliteten som kvantiteten af feedback på skriftligt arbejde. Ligeledes kan det som underviser vore svort at afgive feedback, der tager udgangspunkt i de studerendes respektive loeringssituationer, hvis man ikke har andet afsaet end opgavetekster. Denne artikel beskriver derfor to eksperimenter med brug af selvevaluering som kvalificerende mellemled i ekstern feedback på skriveøvelser. Eksperimenternes formål er at styrke den formative loering ved skriftligt arbejde. I det første eksperiment bestod feedbacken af underviser-feedback, mens det andet eksperiment indebar peer-feedback og faelles feedback. I begge tilfoelde blev selvevalueringen foretaget med udgangspunkt $i$ en kriteriebaseret retteguide. Eksperimenterne medførte, at den eksterne feedback blev målrettet og kvalificeret $i$ forhold til den enkelte studerende, mens selve skriveprocessen mod forventning kun blev påvirket i mindre grad. Endelig blev den formative loering bedst styrket hos de studerende, der i forvejen var engageret $i$ egen loering. En medvirkende årsag hertil var, at nogle studerende oplevede retteguiden som irrelevant eller svort tilgœngelig.

\section{Indledning}

Denne artikel beskriver og diskuterer to eksperimenter, hvor selvevaluering dannede udgangspunkt for ekstern feedback på skriveøvelser i kandidatfaget Innovation og Teknologi på Informationsvidenskab, Aarhus Universitet. Eksperimenterne blev udført som led i forfatterens universitetspædagogikum i efteråret 2015. Formålet var at bruge selvevaluering til at højne kvaliteten af ekstern feedback og derved styrke de studerendes formative læring ved skriftligt arbejde.

Mange studerende på Informationsvidenskab er frustrerede over manglende eller mangelfuld feedback på skriftlige opgaver. En frustration de tilsyneladende deler med deres medstuderende på andre studier og universiteter (Københavns Universitet, 2015; DSF \& Djøf studerende, 2014). Adspurgt om, hvad der typisk frustrerede dem i forbindelse med skriftlige opgaver, problematiserede godt halvdelen af de studerende på Innovation og Teknologi i en anonym spørgeskemaundersøgelse, at der ikke blev afgivet mere ekstern feedback:

"Jeg kan ikke forholde mig til andre feedback-sessioner med underviser, da disse har voret total fravarende. Kun en eller to gange, på snart 3,5 år, har vi fået feedback på det, vi har skrevet (og kun fra instruktor)" (Spørgeskema \#2). 
"Normalt synes jeg ikke, at vi får tilstraekkelig feedback på de opgaver, vi laver. Det giver en følelse af, at vi laver skriveøvelser bare for at gøre det, men uden et egentligt formål"' (Spørgeskema \#2).

Som antydet af de studerende er manglende feedback ikke bare en tabt læringsmulighed, men kan tilmed give studerende det indtryk, at skriftligt arbejde primært er beregnet på underviserens summative vurdering frem for deres egen formative læring (mere herom senere). En betydelig motivation for at forbedre kvaliteten og frekvensen af feedback er således at placere det skriftlige arbejde mere centralt blandt de studerendes foretrukne læringsaktiviteter.

Til problemstillingen hører dog også, at de studerende primært forstod ekstern feedback som underviser-feedback og ikke som peer-feedback. En problemstilling der, som vi skal se, har at gøre med ønsket om validering af opgavens faglige indhold. Ligesom de studerende nok efterlyser mere feedback men samtidig har et meget forskelligartet engagement i forhold til den feedback, der trods alt udbydes. Eksempelvis deltog kun halvdelen af de studerende fra selvsamme kandidatfag i frivillige feedback-sessioner med underviser. Et paradoks der både er velkendt blandt kolleger og velbeskrevet i litteraturens fokus på den fremvoksende overfladestrategi til læring blandt studerende (Biggs \& Tang, 2011, s. 3-16; Herrmann, 2014).

Situationen kan således også være utilfredsstillende for feedback-giver. Det er ressourcekrævende at gennemlæse skriftlige opgaver og forberede kvalificeret feedback. Især fordi de studerendes arbejdsproces og udfordringer kun indirekte fremgår af slutproduktet. Mange undervisere ser sig således nødsaget til at undlade eller overlade feedback-aktiviteter til instruktorer eller studerende. Derudover viser undersøgelser, at mange studerende har svært ved at forstå substansen af den feedback, som de modtager (Nicol \& Macfarlane-Dick, 2006, s. 210; DSF \& Djøf studerende, 2014). Det skyldes blandt andet, at ekstern feedback ofte tager udgangspunkt i uklare eller tavse kriterier, at den i praksis foregår som envejskommunikation, og at der typisk vil være et misforhold mellem forfatterens og læserens forståelse af selvsamme tekst (se også Nicol \& Macfarlane-Dick, 2006).

Det er derfor oplagt at indføre et kvalificerende mellemled for feedback, der dels kan synliggøre de studerendes læring over for feedback-giver og dels kan eksplicitere de gældende kvalitetskriterier og gøre dem til genstand for fælles diskussion. Med inspiration fra Lev Vygotsky (1978) kan man sige, at et sådant mellemled skal synliggøre de studerendes zone for normeste udvikling, altså spændvidden mellem hvad de studerende allerede kan på egen hånd og, hvad de vil kunne lære ved feedback-givers mellemkomst. Hvis skriftligt arbejde derimod primært opfattes som et vurderingsgrundlag, må man formode, at de studerende vil forsøge at tilsløre deres zone for nærmeste udvikling. 
Konkret blev der foretaget to eksperimenter i forlængelse af hver deres skriveøvelse. I begge tilfælde blev der udleveret en kriteriebaseret retteguide sammen med opgaveformuleringen, som de studerende udfyldte og afleverede som bilag til skriveøvelsen. ${ }^{1}$ I første eksperiment dannede selvevalueringen udgangspunkt for individuel, mundtlig feedback fra underviser. I andet eksperiment dannede selvevalueringen udgangspunkt for peer-feedback i grupper efterfulgt af fælles feedback fra underviseren. I forlængelse af hvert eksperiment blev der foretaget en anonym spørgeskemaundersøgelse, der refereres til som henholdsvis 'spørgeskema \#1' og 'spørgeskema \#2'.

Der var tale om praksiseksperimenter beregnet på egen læring, hvorfor der ikke på forhånd blev opstillet nogen specifik forskningsmetode. Eksperimenternes design og udførsel afspejler dog den gældende faglighed på Informationsvidenskab, hvor der er tradition for at kombinere pragmatiske og kvalitative forskningsmetoder med iterative og agile udviklingsprocesser (Dalsgaard, 2010). Bestræbelserne på at designe et koncept for feedback gennem selvevaluering udgør således også en kvalitativ runddans omkring temaerne selvevaluering, feedback og skriftligt arbejde (Wadel, 1991).

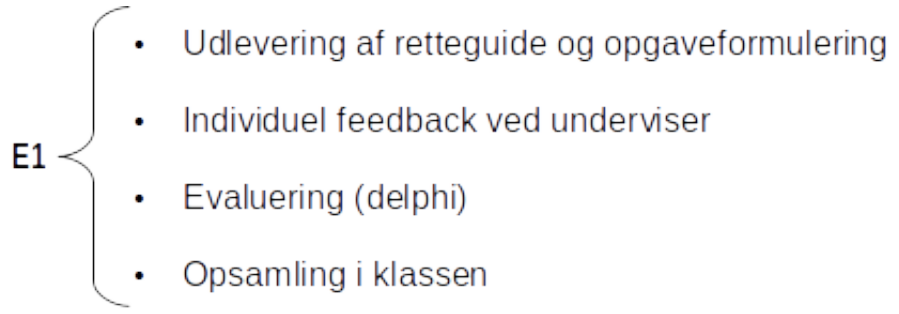

- Tilpasning af retteguide

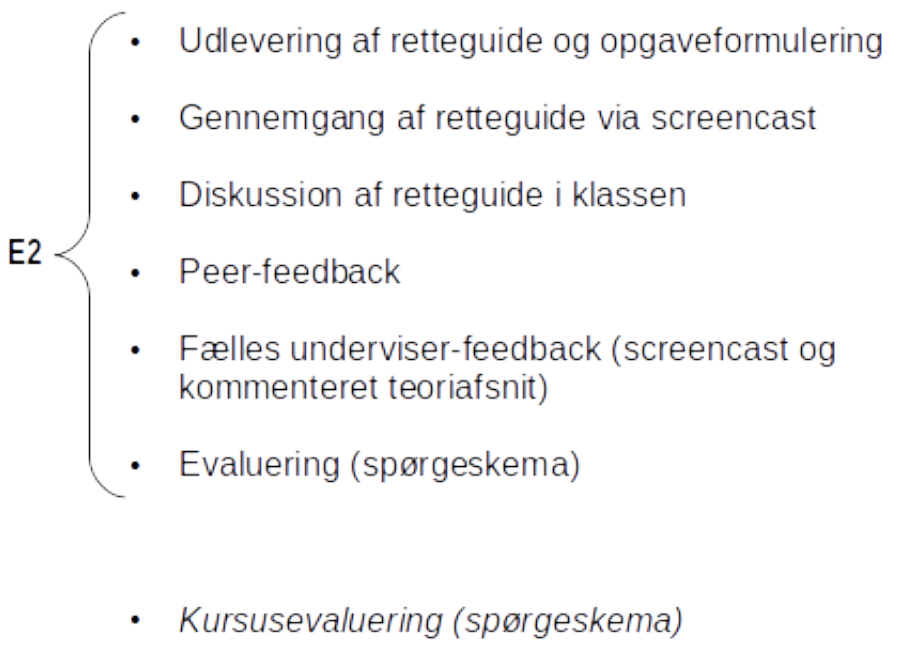

Illustration 1: Proceslinje over eksperimenternes forløb.

${ }^{1}$ Retteguiden kan tilgås online her: http://goo.gl/omRp5J. 
Artiklen forløber som følger: Indledningsvist beskrives det fag og den kontekst, hvori eksperimenterne er udført. Dernæst redegøres der nærmere for de didaktiske overvejelser omkring selvevaluering, feedback og skriftligt arbejde. Herefter diskuteres eksperimenterne hver for sig inden det afslutningsvis diskuteres, i hvilken udstrækning eksperimenterne bidrog til formativ læring ved skriftligt arbejde og ikke mindst for hvem.

\section{Eksperimenternes kontekst: Kandidatfaget Innovation og Teknologi}

Kurset i Innovation \& Teknologi (20 ECTS) fungerer som et ud af to mulige grundforløb på kandidatuddannelsen i Informationsvidenskab - en humanistisk IT-uddannelse på Aarhus Universitet. Ifølge studieordningen er kursets formål dels at sætte de studerende i stand til at analysere innovationsprocesser og dels at perspektivere, supplere og diskutere traditionelle begreber om innovation med teori fra deres kernefaglighed. I efteråret 2015 fulgte 24 studerende kurset, der primært foregik som holdundervisning.

Overordnet har kurset to indholdselementer, der i praksis opdeler semestret i to kvarterer. I første kvarter gennemgås økonomisk og forretningsorienteret innovationsteori (de traditionelle innovationsbegreber). I andet kvarter gennemgås samfundsvidenskabelige og humanistiske studier af teknologi, videnskab og innovation (fra det såkaldte STS-felt). Begge kvarterer afsluttes med en skriveøvelse med et omfang på 5 sider og en fast problemformulering. Det var efter disse skriveøvelser, at eksperimenterne med selvevaluering og feedback blev foretaget.

Skriveøvelserne skal forberede de studerende på eksamen, der i prøveform A består af en bunden hjemmeopgave på 15-20 sider. De studerende trækker et ud af syv mulige eksamensspørgsmål, som de efterfølgende har 14 dage til at besvare. De forskellige eksamensspørgsmål er baseret på samme type formuleringer som skriveøvelserne, der derfor skal træne de studerendes evne til at afkode, hvad der menes med begreber såsom at redegøre, motivere, identificere, diskutere, argumentere, osv.

\section{Didaktiske overvejelser omkring selvevaluering, feedback og skriftligt arbejde}

Selvevaluering er højt placeret på effektlister over didaktiske metoder (Dochy, Segers \& Sluijsmans, 1999; Hattie, 2015; Nicol \& Macfarlane-Dick, 2006). Det er måske ikke overraskende, da studerende, der er aktive i egen læring, i forvejen udøver en god portion selvevaluering og selvregulering i deres læringsprocesser (se fx Biggs \& Tang, 2011, s. 61). Og som Jens Christensen (2008, s. 17) skriver, er der en åbenlys sammenhæng mellem studerendes autonomi og deres læringsudbytte. Derudover kan man betragte selvevaluering som en almen akademisk kompetence, idet det akademiske arbejde til stadighed forudsætter individuel evne til at tilegne sig ny viden på et højt niveau. Det er derfor centralt, at alle studerende - også de, der har dårlige forudsætninger - tilegner sig kompetencer til at evaluere egen forståelse og læring (Dochy et al., 1999).

Det er således vigtigt, at selvevaluering er formativ frem for summativ. De to vurderingsog evalueringsformer markerer en afgørende forskel mellem at identificere 'det næste 
skridt' i en læringsproces og at konkludere på en allerede opnået forståelse - ofte med henblik på rapportering til en ekstern tredje part (Harlen \& James, 1997, s. 369-70). Populært sagt skal den summative evaluering identificere fejl, mangler og misforståelser eksempelvis tæller 7-trins skalaen ned fra 12 - mens den formative skal identificere videre læringsmål i en fortsat læringsproces.

Skriftligt arbejde er en udbredt eksamensform og risikerer derfor at blive tæet knyttet til summative formål. I spørgeskema \#2 blev de studerende bedt om at beskrive en ting, som typisk havde frustreret dem ved skriftligt arbejde. Her omhandlede 8 ud af 18 besvarelser manglende feedback, og konsekvenserne for de studerendes forståelse af skriftligt arbejde var tydelige:

"Det [manglende feedback] resulterer $i$, at opgaven i højere grad kommer til at fungere som noget, underviser kan bruge til at vurdere, om jeg kan mine ting" (Spørgeskema \#2).

Andre studerende supplerede med en holdning, der har samme konsekvens, men som også er udtryk for en udpræget eksamensorienteret studiestrategi (se også Rottbøll, 2012):

"Manglende incitament for at skrive noget ordenligt; vi får jo ikke karakter, og man slipper jo igennem så loenge man afleverer noget, der opfylder" (Spørgeskema \#2).

Hvis det skriftlige arbejde således i højere grad skal indgå i formativ læring, så må den efterfølgende feedback nødvendigvis eksplicitere både, hvad der kendetegner en god forståelse på området, hvordan den studerendes forståelse adskiller sig fra denne, og hvad den studerende kan gøre for at lukke hullet (Sadler citeret i Nicol \& MacfarlaneDick, 2006, s. 204).

En kriteriebaseret retteguide blev derfor udarbejdet som udgangspunkt for selvevalueringerne. Retteguiden bestod primært af undervisers kriterier for en god skriveøvelse, men forud for andet eksperiment blev der også tilføjet plads til studerendes egne kriterier (mere herom senere). Konkret beskrev retteguiden en række målsætninger, der blev udfoldet i længere tekstpassager. Fra forskellige angrebsvinkler skulle målsætningerne træne de studerende i skriftlig akademisk argumentation. De studerende skulle beskrive i hvor høj grad de opfyldte en given målsætning i prosa samt bedømme sig selv med en karakter fra 7-trinsskalaen.

Det var selvfølgelig risikabelt at bruge 7-trinsskalaen til formativ evaluering, idet den jo også anvendes summativt til eksamensformål, men jeg ville gerne introducere de studerende til skalaens formål og virkemåde: nemlig at vurdere dem individuelt i forhold til et givent og kriteriebaseret læringsmål (Ministeriet for Børn, Undervisning og Ligestilling, 2015). På den måde var formålet dels at anskueliggøre, hvordan deres eksamens- 
opgaver ville blive bedømt, og dels at tvinge dem til at blive konkrete ved at talsætte deres selvevaluering.

Alle målsætninger havde det formål, at de studerende skulle betragte teksten og skriveprocessen som en måde at udforske og udfordre deres forståelse af et givent emne. Til dette formål indeholdt retteguiden underviserens egne 7 kvalitetskriterier samt en omformuleret version af SOLO-læringstaksonomien, der indeholder en række verber, som kan spores i forfatterens tekst og derved hjælpe med at tydeliggøre, hvor god en forståelse teksten repræsenterer (se også SOLO-taksonomien i bilag). Hensigten var således, at de studerende kunne reflektere over deres læringsniveau på en tekstnær måde.

\section{Første eksperiment: selvevaluering efterfulgt af underviser-feedback}

Det første eksperiment med selvevaluering blev efterfulgt af individuel feedback fra underviser. Forud for feedback-sessionerne havde jeg tilføjet min vurdering til de studerendes selvevaluering, og under selve sessionerne brugte jeg opgaveteksten til at eksemplificere kritikpunkter fra retteguiden. Alle studerende blev tilbudt 20 minutters individuel mundtlig feedback. Desværre var det dog kun 14 ud af 24 studerende, der valgte at gøre brug af feedbackmuligheden.

Afslutningsvis blev processen evalueret online via en tilpasset Delphi-metode (Hsu \& Sandford, 2007). Konkret blev de studerende, der havde modtaget feedback, hver især bedt om at redegøre for, hvordan retteguide og selvevalueringen havde indvirket på deres skriveproces og, hvordan de havde oplevet den eksterne feedback. Dernæst vægtede de hinandens indlæg. Evalueringen var frivillig og anonym og havde en svarprocent på kun 50\%. I det hele taget tydeliggjorde første eksperiment og dets evaluering meget forskellige niveauer af frivillig engagement i ikke-obligatorisk feedback på skriveøvelser - selv når denne kom fra underviser.

\section{Erfaringer fra første eksperiment}

Der var tre formål med første eksperiment: 1) At undersøge hvorvidt og hvordan retteguiden i sig selv kunne facilitere formativ læring under skriveprocessen. 2) At undersøge hvor godt et kendskab selvevalueringer bibringer feedback-giver omkring de studerendes egen forståelse af såvel deres tekst som de gældende kvalitetskriterier. Og 3) at undersøge på hvilke måder selvevalueringerne kunne styrke den formative læring ved ekstern feedback.

For at starte med sidstnævnte var de studerendes oplevelse af feedback-kvaliteten særdeles positiv. De højest vægtede bidrag til evalueringen betonede, at feedbacken virkede afklarende i forhold til kriterierne for den gode opgave, at formen var dialogisk frem for transmitterende og, at der var en god vekselvirkning mellem opgavens konkrete tekstpassager og retteguidens mere almene målsætninger: 
"[...] Jeg følte, jeg fik meget ud af det - både ift. det jeg skrev i opgaven, men også ift. hvad du forventer til eksamen. Det var rart at få uddybet tingene, også med eksamen. Du gav plads til at gå uden om opgaven $i$ samtalen også, som var gavnligt. Så tak for det. Og vigtigst af alt, så var det ikke bare dig, der snakkede TIL mig, men vi snakkede sammen om opgaven [...]" (Spørgeskema \#1).

"[...] Du havde både voeret tekstncer og fokus på den store sammenhceng og rød tråd $i$ opgaven. Samt fik jeg masser af brugbar feedback, råd og tricks jeg kan tage med til eksamen [...]" (Spørgeskema \#1).

Ligeledes var selvevalueringerne en stor hjælp i min forberedelse som underviser. De reducerede ikke arbejdstiden, men de fokuserede min forberedelse og målrettede på et tidligt tidspunkt de feedback-punkter, som jeg mente ville være mest relevante for pågældende studerende. Kort sagt blev opgaverne lettere at læse med en feedbackdagsorden.

Omvendt var eksperimentet mindre succesfuldt i forhold til, hvorvidt retteguiden i sig selv kunne medføre formativ læring. Guiden blev beskrevet som et godt redskab til feedback-sessionen men som et "forstyrrende element" under skriveprocessen, hvor de studerende havde svært ved at forholde sig til målsætningerne. Særligt SOLOtaksonomien var svær at arbejde med:

"Jeg så først på den [retteguiden] efter jeg havde skrevet, og den var for det meste brugbar og gav øjenåbnere. Det ville dog nok vaere givtigt med en forholdsvis grundig gennemgang, da nogle af vurderingerne var svcere for mig at foreholde sig til (primoert loeringsniveau)" (Spørgeskema \#1).

"Men den klargjorde helt sikkert også nogle ting, jeg normalt ikke toenker over, når jeg skriver en opgave, som jeg da vil toenke mere over nu" (Spørgeskema \#1).

Retteguiden blev altså primært anvendt som en eftertanke og burde have været introduceret grundigere med mere diskussion af kriterierne.

Erfaringen fra første eksperiment blev således, at selvevalueringen nok skabte grundlag for nye refleksioner men ikke nævneværdigt formede de studerendes skriveproces, at underviser fandt, at selvevalueringerne styrkede den afgivne feedback ved dels at give et indblik i de studerende læring og dels at bidrage med en fælles og eksplicit referenceramme, og at de studerende oplevede feedbacken som lærerig og dialogisk.

\section{Andet eksperiment: selvevaluering og peer-feedback}

På baggrund af erfaringerne fra første eksperiment blev en række nye tiltag forsøgt i andet eksperiment, der fulgte samme formel med retteguide udleveret sammen med opgaveformulering, selvevaluering og ekstern feedback. Deltagelse blev gjort obligato- 
risk, ligesom den efterfølgende evaluering blev foretaget i en konfrontationstime, hvilket resulterede i en deltagelsesprocent i feedbacken på 83\% (20 ud af 24) og en svarprocent i den efterfølgende evaluering på 70\% (17 ud af 24). Retteguiden blev ligeledes omformuleret. Særligt blev SOLO-taksonomien forsimplet og gennemgået sammen med resten af guiden i et screencast. ${ }^{2}$ Der blev desuden tilføjet et felt, hvor de studerende kunne angive hvilke punkter, de selv ønskede feedback på.

Derudover blev den individuelle underviser-feedback erstattet med peer-feedback i grupper, alt imens underviserne foretog fælles feedback i form af et screencast og et kommenteret teoriafsnit. Evalueringsformen skiftede desuden til en mere omfattende spørgeskemaundersøgelse, der dels spurgte mere struktureret ind til feedbacksituationen og dels bidrog med nogle mere sammenhængende studenterprofiler. ${ }^{3}$

\section{Erfaringer fra andet eksperiment}

Der var denne gang tre formål med eksperimentet: 1) At fortsætte undersøgelsen af hvorvidt den nu mere velkendte retteguide i sig selv kunne indvirke på de studerendes skriveproces. 2) At undersøge hvorvidt den styrkelse af formativ feedback, som havde kendetegnet første eksperiment, også ville gøres sig gældende ved peer-feedback. Og 3) at undersøge hvorvidt selvevalueringerne ligeledes kunne styrke relevansen af fælles-feedback fra underviser.

Med den omformulerede retteguide lykkedes det nogenlunde at eksplicitere målsætninger og kvalitetskriterier på en måde, så de greb ind i de studerendes skriveproces. Det havde dog været ønskværdigt, hvis jeg i højere grad havde diskuteret guiden med de studerende og positioneret de studerendes egne kriterier mere centralt i processen. Således oplevede omkring 40\% af de studerende, at målsætningerne og de ekspliciterede kriterier i retteguiden nu influerede positivt på deres skriveproces:

"Jeg synes retteguiden fungerede fint, da den var en stor hjoelp, så jeg kunne finde ud af, hvad jeg skulle fokusere på for at lave en god opgave" (Spørgeskema \#2).

"Den virkede sådan set fint nok, den var med til at strømline og fokusere opgaven. Den gav ligeledes en rød tråd at tage udgangspunkt i" (Spørgeskema \#2).

Omvendt fandt flertallet dog stadig, at retteguiden ikke influerede på skriveprocessen, men mere stimulerede refleksioner efter aflevering i forbindelse med feedback:

"Den gav mig nogle interessante oplevelser ift. at skulle forholde mig til min egen skrivning [...] men det havde ikke den store indflydelse på selve skrivningen af min opgave. Den gav refleksioner efter opgaven var lavet" (Spørgeskema \#2).

\footnotetext{
${ }^{2}$ Screencastet kan tilgås på https://www.youtube.com/watch?v=ET6JF0-5xF4.

${ }^{3}$ Spørgeskemaet kan ses her: http://goo.gl/fpPoCE.
} 
Til peer-feedback-workshoppen fik hver studerende feedback fra to medstuderende, der havde kommenteret opgavens brødtekst i Google Docs og tilføjet deres vurdering til modtagerens selvevaluering.

Halvdelen af de studerende tog godt imod kombinationen af peer-feedback og selvevaluering, mens de resterende enten var indifferente eller fandt retteguiden overflødig. Nogle grupper valgte desuden helt at tilsidesætte retteguiden i deres feedback til hinanden, hvilket også peger på, at retteguiden i større omfang skulle have været diskuteret og forhandlet med de studerende.

På den positive side oplevede godt halvdelen af de studerende, at de med afsæt i selvevalueringen følte sig bedre i stand til at målrette og kvalificere den feedback, som de skulle afgive: "Jeg brugte flere principper derfra til at argumentere for mine rettelser" som en studerende beskrev det (Spørgeskema \#2). Den samme halvdel oplevede ligeledes, at den feedback de selv modtog, var bedre struktureret og af en højere kvalitet:

"Det gjorde, at der var en struktur i den feedback, jeg fik, og at feedbacken ikke bare skød i tusinde retninger" (Spørgeskema \#2).

"Den muliggjorde både tekstnaer og generel feedback, som spredte sig over forskellige områder. Virkede fint" (Spørgeskema \#2).

"Jeg tror det gjorde, at den feedback jeg fik, var mere målrettet" (Spørgeskema \#2).

Hvad angår eksperimentets sidste punkt - hvorvidt selvevalueringerne kunne styrke den individuelle relevans af undervisernes fælles feedback - så blev resultatet mere uklart. En gennemlæsning af selvevalueringerne synliggjorde de problemstillinger, som holdet som helhed havde en uklar forståelse af. På den baggrund blev der som omtalt produceret et screencast og et kommenteret teoriafsnit til fælles feedback. Og selvom flere fandt den fælles feedback brugbar, blev screencastet kun set af 13 studerende, mens teoriafsnittet kun blev læst af 9 ud af samlet 24 studerende (angivet af de studerende selv i den efterfølgende evaluering).

Samtidig afslørede evalueringen en kritisk holdning til fælles feedback blandt de studerende, der havde fravalgt at se screencastet eller læse teoriafsnittet. Mange efterspurgte samtidig underviser-feedback frem for peer-feedback:

"Det havde voret rart med individuel feedback. Det var fedt med feedback fra de andre, men jeg vil nok vœre endnu mere sikker i min forståelse, hvis jeg også havde fået feedback fra dig, Lars" (Spørgeskema \#2).

Som antydet af flere studerende, så var det særligt den teorinære validering af deres pensumforståelse, som de ikke fandt tilstrækkelig i peer-feedbacken eller individuel nok i den fælles feedback. En problematik, der måske kunne løses ved at gøre retteguidens kriterier mere teorinære. 


\section{Diskussion}

Formålet med at eksperimentere med feedback og selvevaluering var at styrke den formative læring ved de studerendes skriftlige arbejde. Både ved underviser-feedback og ved workshoppen med peer-feedback oplevede de studerende, at selvevalueringen fokuserede og kvalificerede den feedback, de modtog. Ligeledes oplevede feedbackgiverne, at selvevalueringen gav kendskab til forfatterens egen forståelse af teksten og derved gjorde det lettere at identificere de steder, hvor man som feedback-giver kunne bidrage til vedkommendes videre læring.

Det blev dog også tydeligt, at retteguiden og selvevalueringen i sig selv ikke medførte megen formativ læring. I hvert fald ikke for flertallet, der nok skulle have været inddraget mere i processen omkring at udarbejde guidens målsætninger, ligesom der kunne have været mere aktiv brug af individuelle læringsmål. Som en studerende polemisk beskrev det: "Der er lidt for meget kancelli/bureaukratisk kommunesprog over den [retteguiden]" (Spørgeskema \#2). Et oplagt punkt til videre undersøgelse vil desuden være at komme tættere på, hvordan de studerende i praksis arbejder med selvevalueringen - fx gennem deltagerobservationer.

Den afsluttende evaluering af Innovation og Teknologi tegner desuden et billede af, at selvevalueringer særligt gavnede de studerende, der i forvejen var engagerede i deres egen læring. I evalueringen blev de studerende bedt om at redegøre for deres studiestrategi på forskellig vis, hvilket tydeliggjorde hele spændvidden af studiestrategier fra eksamensorienteret overfladelæring til engageret dybdelæring (Biggs \& Tang, 2011, s. 5). ${ }^{4}$ Her er det sigende, at de 10 studerende, der eksplicit nævner feedbackeksperimenterne blandt de læringsaktiviteter, som fungerede godt på kurset, samtidig har angivet en ugentlig forberedelsestid, der er væsentlig højere end deres medstuderende samtidig med, at de også har angivet et moderat højere læringsudbytte af kurset (da evalueringen er anonym, har det desværre ikke været muligt at sammenligne med eksamenskarakterer). Noget tyder altså på, at Kim Herrmann (2014) har ret i, at studenter-centrerede læringsaktiviteter - hvorunder jeg grupperer feedback-eksperimenterne - ikke nødvendigvis er bedre til at fange studerende med overfladestrategier end de traditionelle forelæsninger.

Hvorom alting er, så har flere studerende angivet både over for underviser og i den endelige evaluering, at den kvalificerede feedback gjorde en reel forskel. En studerende skriver ligefrem, at vedkommende lærte meget om sig selv i forhold til skriftlige opgaver, mens en anden foreslår ugentlige skriveøvelser med feedback af samme type i alle fag på kandidatniveau. Der er altså gode perspektiver i at arbejde med kvalificerende mellemled a la selvevalueringer, hvis feedback-kvaliteten skal styrkes og, hvis det skriftlige arbejde skal placeres mere centralt i de studerendes formative læring.

\footnotetext{
${ }^{4}$ Spørgeskemaet kan ses her: http://goo.gl/BULeKo.
} 
Lars Bo Andersen er postdoc ved Informationsvidenskab på Aarhus Universitet. Han forsker i forholdet mellem teknologi og mennesker med en saerlig interesse for sociale forandringsprocesser: fra udviklingsprojekter med skolecomputere i Afrika til dialogplatforme med anbragte børn og unge i Danmark. Lars arbejder med etnografiske metoder og teorier fra det tvoerfaglige felt Science and Technology Studies - med en scerlig interesse for Aktør-Netvarks Teori og andre "procesfilosofier". Derudover underviser han på alle niveauer i emner såsom organisation, arbejdspraksis, metode, innovation og empowerment.

\section{Litteratur}

Biggs, J. B. \& Tang, C. (2011). Teaching for Quality Learning at University: What the Student Does (4. ed). Maidenhead. McGraw-Hill [u.a.].

Christensen, J. P. (2008). Hvad er god undervisning? I J. P. Christensen (Overs.): Hvad vi ved om god undervisning. København: Dafolo.

Dalsgaard, P. (2010). Research in andthrough design - an interaction design research approach. In Proceedings of OZCHI 2010.

Dochy, F., Segers, M. \& Sluijsmans, D. (1999). The use of self-, peer and coassessment in higher education: a review. Studies in Higher Education, 24(3), 331-350.

DSF \& Djøf studerende. (2014). Vores uddannelser - vores løsninger. København.

Foucault, M. (1998). The Will to Knowledge. (R. Hurley, Overs.) (Amended reprint). London: Penguin Books.

Harlen, W. \& James, M. (1997). Assessment and learning: differences and relationships between formative and summative assessment. Assessment in Education: Principles, Policy \& Practice, 4(3), 365-379.

Hattie, J. (2015). Hattie Ranking: Influences And Effect Sizes Related To Student Achievement. Hentet 3. Oktober 2015, fra http://visible-learning.org/hattieranking-influences-effect-sizes-learning-achievement/

Herrmann, K. J. (2014). Learning from tutorials: a qualitative study of approaches to learning and perceptions of tutorial interaction. Higher Education, 68(4), 591606.

Hsu, C.-C. \& Sandford, B. A. (2007). The Delphi technique: Making sense of consensus. Practical Assessment, Research \& Evaluation, 12(10), 1-8.

Københavns Universitet. (2015). Feedback på KU - Rapport fra taskforcen vedr. feedback til studerende. Hentet fra

http://uddannelseskvalitet.ku.dk/udviklingsinitiativer/feedback/dokumenter/Fe edback_p_KU._20.05.15.pdf

Ministeriet for Børn, Undervisning og Ligestilling. (2015). Anvendelse af 7-trinsskalaen. Ministeriet for Børn, Undervisning og Ligestilling. Retrieved from http://uvm.dk/Uddannelser/Paa-tvaers-af-uddannelserne/7-trinsskalaen/Anvendelse-af-7-trins-skalaen 
Nicol, D. J. \& Macfarlane-Dick, D. (2006). Formative assessment and self-regulated learning: A model and seven principles of good feedback practice. Studies in Higher Education, 31(2), 199-218.

Rottbøll, E. (2012, Oktober 10). Er det noget, vi skal kunne til eksamen? Information. Hentet fra http://www.information.dk/313361

Vygotsky, L. S. (1978). Mind in Society: The Development of Higher Psychological Processes. Cambridge, Mass.: Harvard University Press.

Wadel, C. (1991). Feltarbeid i egen kultur - en innføring i kvalitativt orientert samfunnsforskning. Flekkefjord. 